Georgetown University Law Center

Scholarship @ GEORGETOWN LAW

2001

\title{
Can They Do That? Legal Ethics in Popular Culture: Of Characters and Acts
}

Carrie Menkel-Meadow

Georgetown University Law Center, meadow@law.georgetown.edu

This paper can be downloaded free of charge from:

https://scholarship.law.georgetown.edu/facpub/170

48 UCLA L. Rev. 1305-1337 (2001)

This open-access article is brought to you by the Georgetown Law Library. Posted with permission of the author. Follow this and additional works at: https://scholarship.law.georgetown.edu/facpub

Part of the Legal Ethics and Professional Responsibility Commons 


\title{
GEORGETOWN LAW Faculty Publications
}

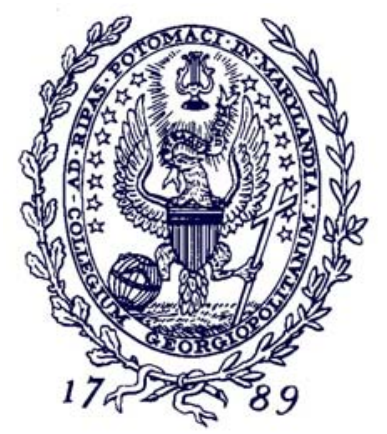 \\ January 2010

\section{Can They Do That? \\ Legal Ethics in Popular Culture: Of Characters and Acts}

48 UCLA L. Rev. 1305-1337 (2001)

\author{
Carrie Menkel-Meadow \\ Professor of Law \\ Georgetown University Law Center \\ meadow@law.georgetown.edu
}

This paper can be downloaded without charge from:

Scholarly Commons: http://scholarship.law.georgetown.edu/facpub/170/

SSRN: $\underline{\text { http: // ssrn.com/abstract }=288803}$

Posted with permission of the author 


\title{
CAN THEY DO That? Legal ETHICS IN POPUlaR CULTURE: OF CHARACTERS AND ACTS
}

\author{
Carrie Menkel-Meadow ${ }^{*}$
}

This Essay describes the depiction of modern lawyers' professional ethics in literature, films, and television, and distinguishes between personal and professional character and specific acts. Depictions of lawyers in modern popular culture are more complex and nuanced than older treatments and allow law students, lawyers, and legal academics an opportunity to examine both ethical rule violations and "micro" behavioral choices, as well as character and more "macro" professional career choices and philosophies in a variety of contexts and serialized plot treatments. Treatments of professional ethics in more recent popular culture are also contrasted to more literary examinations of both lawyers' and other professionals' moral choices. Whether modern popular depictions of lawyers reveal more villains than heroes remains an interesting, if unanswerable question. Lawyers are more diverse in their demography and work settings, and the complexity of the sociology of ethical choices is now more often depicted than it was in the "golden age" of popular lawyer heroes.

INTRODUCTION.

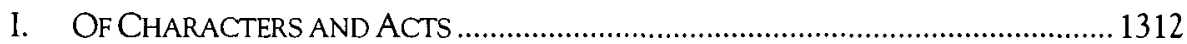

II. LEGAL ETHICS CHARACTERS IN POPULAR CULTURE ......................................... 1315

III. THE ETHICS OF ACTS IN POPULAR CULTURE .............................................. 1325

IV. Professional Ethics In Popular CultURE ............................................... 1333

\section{INTRODUCTION}

Consider these two thought experiments: First, what was your first image of a lawyer and where did it come from? Was the lawyer a "good" lawyer? A "good" person? Did the lawyer do good deeds or commit bad

* Professor of Law, Georgetown University Law Center; Visiting Professor of Law, Harvard Law School, Spring 2001; Chair, Georgetown-CPR Institute for Dispute Resolution Commission on Ethics and Standards in Alternative Dispute Resolution. Thanks to my research assistants, I. Glenn Cohen at Harvard and Meredith Weinberg at Georgetown, for excellent research assistance and up-to-date cultural criticism. Thanks to Michael Asimow, my former colleague and continuing friend, for organizing this symposium and providing many opportunities for conversations and scholarship about lawyers and law in popular culture. And special thanks to Robert Meadow, my partner in crime-watching (and lawyerly activities) and my lay-legal ethics expert who often asks, "Can they do that?" 
acts? Did your first image of a lawyer come from real life or from a movie, a television show, a popular novel, or literature?'

Second, what popular, cinematic, or literary image would you select as being "exemplary" of the good lawyer? Do you imagine a person of good character or one who does good deeds? Who seeks justice, possibly at great personal or professional risk to self, or who is "good or helpful" to other people, including clients and third parties? Is a "good" lawyer a person who performs his or her craft well or a person who is fair, kind, and just? Do you see a courtroom trial advocate, ready with razor sharp questions and pithybut moving-closing arguments? Do you see a skillful draftsperson or law office counselor advising people to do the right thing or create new and interesting entities?

Many critics of lawyers in popular culture have argued about whether recent images of lawyers in movies, popular novels, legal thrillers, and even more complex "high" literature reveal a declining ethicality, or faith and trust in lawyers. Some separate the heroes from the villains, and see a decline in the heroism of lawyers. ${ }^{2}$ Others see a more complicated alternation of good and bad images of lawyers in American history as different periods of American cultural representations reflect the vagaries of historical appreciation or deprecation of lawyers, beginning with the period immediately after the American Revolution, and-most agreeculminating in the zenith or "golden age" of lawyer appreciation in the films of the late 1950s and early 1960s. ${ }^{3}$ From a period of virtual or actual

1. For my recent discussions of sources of lawyer images and ethical models in both "high" literature and popular culture, see Carrie Menkel-Meadow, Telling Stories in School: Using Case Studies and Stories to Teach Legal Ethics, 69 FORDHAM L. REV. 787 (2000) [hereinafter MenkelMeadow, Telling Stories], and Carrie Menkel-Meadow, The Sense and Sensibilities of Lawyers: Lawyering in Literature, Narratives, Film and Television, and Ethical Choices Regarding Career and Craft, 31 MCGEORGE L. REV. 1 (1999). For other scholars' treatments of the images of lawyers derived from popular culture, see, for example, Anthony Chase, Lawyers and Popular Culture: A Review of Mass Media Portrayals of American Attomeys, 1986 AM. B. FOUND. RES. J. 281, and Robert C. Post, On the Popular Image of the Lawyer: Reflections in a Dark Glass, 75 CAL. L. REV. 379 (1987). For a description of lawyers' images derived from actual interviews with both lay people and lawyers, see Marvin W. Mindes \& Alan C. Acock, Trickster, Hero, Helper; A Report on the Lawyer Image, 1982 AM. B. FoUND. RES. J. 177. See also The Lauryer in Popular Culture: A Bibliography, available at http://www.law.utexas.edu/lpop/lpopbib2.htm (last visited July 29, 2001) (providing the University of Texas Law School Tarlton Law Library's compilation of works on the issue of popular culture and the law).

2. See, e.g., Michael Asimow, Bad Lawyers in the Movies, 24 NovA L. REv. 531 (2000) [hereinafter, Asimow, Bad Lawyers]; Michael Asimow, When Lawyers Were Heroes, 30 U.S.F. L. REV. 1131 (1996); Michael Asimow, Lauryers as Fallen Idols: Whatever Happened to Our Golden Image?, NAT'L L.]., Feb. 8, 1999, at A22.

3. See, e.g., Chase, supra note 1 (attributing the "golden age" to the champions of individual civil liberties and group civil rights in fiction, modeled on some realities); see also Maxwell Bloomfield, Law and Lawyers in American Popular Culture, in LAW AND AMERICAN LITERATURE: 
canonization of such figures as Atticus Finch, ${ }^{4}$ Sir Thomas More ${ }^{5}$ and television's The Defenders, ${ }^{6}$ we are now in a period that not only creates its own more morally and ethically ambiguous lawyers, but also seems to be engaged in some revisionist re-readings of even such heroes as Atticus Finch.? With the vast increase in novels, mysteries, thrillers, movies, ${ }^{8}$ and television shows about lawyers, images of lawyers-good, bad, indifferent, complicated, and nuanced-are proliferating. These recent depictions present a greater variety of lawyer images to choose from, which, while perhaps still not "representative" (in a socially scientific way) of all lawyers, present a more accurate choice of complex lawyer images to analyze than ever before.

As I will suggest in this Essay, the greater variety of genres and increasing numbers of lawyers in popular literature and culture present an excellent opportunity for students of legal ethics to examine the work of lawyers in both their "macro" (choice of career, choice of client, role in legal institutions) and "micro" (choice of particular actions and behaviors) contexts, and allow us to examine the many different criteria we might apply to evaluate whether a lawyer is a good or bad actor, or a good or bad person." It is also interesting to ask why lawyers have so frequently been

A COLLECTION OF ESSAYS 125 (Carl S. Smith et al. eds., 1983); Lawrence M. Friedman, Law, Lawyers and Popular Culture, 98 YALE L.J. 1579 (1989); Marc Galanter, The Faces of Mistrust: The Image of Lawyers in Public Opinion, Jokes, and Political Discourse, 66 U. CIN. L. REV. 805 (1998); Stewart Macaulay, Popular Legal Culture: An Introduction, 98 YALE L.J. 1545 (1989); Francis Nevins, Law, Lawyers and Justice in Popular Fiction and Film, HUMAN. EDUC., May 1984, at 3.

4. See HARPER LeE, To Kill A MOCKINGBIRD (1960); Monroe Freedman, Argumentum ad Hominem: Atticus Finch as Hero?, N.J. L.J., Mar. 1992, at 15; Thomas L. Shaffer, The Moral Theology of Atticus Finch, 42 U. PITT. L. REV. 181 (1981).

5. See Robert Bolt, A Man for All Seasons (1960); A Man for All Seasons (Columbia Pictures 1966) (starring Paul Scofield, Wendy Hiller, Leo McKern, Orson Welles, and Susannah York).

6. The Defenders (CBS television broadcast, 1961-1965); see David Ray Papke, The Defenders, in PRIMe Time Law: Fictional Television as Legal Narratives 3 (Robert M. Jarvis \& Paul R. Joseph eds., 1998).

7. See Monroe H. Freedman, Atticus Finch-Right and Wrong, 45 ALA. L. REV. 473 (1994); Steven Lubet, Reconstructing Atticus Finch, 97 MICH. L. REV. 1339 (1999); John Jay Osborn, Jr., Atticus Finch-The End of Honor: A Discussion of To Kill a Mockingbird, 30 U.S.F. L. Rev. 1139 (1996); Teresa Godwin Phelps, The Margins of Maycomb: A Rereading of To Kill a Mockingbird, 45 ALA. L. REV. 511 (1994); Joseph Crespino, The Strange Career of Atticus Finch, S. CULTURES, Summer 2000, at 9.

8. See Tim Appelo, Atticus Doesn't Live Here Anymore, CAL. LAW., Aug. 1992, at 174; David Margolick, The Cinematic Law Firm of Greedy, Vain \& Immoral, N.Y. TIMES, July 4, 1993, $\S 2$, at 9 .

9. In a recent article, more fully discussed in the text, William Simon has recently argued that modern depictions of lawyers on television and in popular novels demonstrate lawyers utilizing more nuanced actions or what he calls "moral pluck," that are more deeply affected by context and discretionary choices than by the mechanistic application of the Model Rules of Professional Conduct. See William H. Simon, Moral Pluck: Legal Ethics in Popular Culture, 101 COLUM. L. REV. 421 (2001) lhereinafter Simon, Moral Pluck]. Simon's readings of John Grisham's protagonists 
depicted as the repositories of professional morality, and used in critiques of morality in American culture, compared to other professionals with ethical dilemmas such as doctors, ${ }^{10}$ architects, ${ }^{11}$ police officers, ${ }^{12}$ and business managers, ${ }^{13}$ not to mention other kinds of workers (such as British butlers, ${ }^{14}$ or French executioners ${ }^{15}$ ), and ordinary human beings. I will focus here on some comparative professional ethics, as depicted in popular culture and literature, as another way of looking at how ethics are presented in modern culture and to illustrate how lawyers have come to be considered one bellwether of American morality.

The variations of genre allow different aspects of the lawyer's persona to be developed. Long novels and television series allow "character" to be more fully developed. ${ }^{16}$ Movies and superficial thrillers or mysteries tend to

and the lawyers on L.A. Law (NBC television broadcast, 1986-1994) and The Practice (ABC television broadcast, 1997-current) comport with his arguments that all lawyers should engage in more discretionary ethical deliberation, depending on the context and situation in which legal ethics problems arise. See William H. Simon, THE Practice of JusticE: A. THEORY OF LAWYERS' ETHICS (1998); William H. Simon, Ethical Discretion in Lawyering, 101 HARV. L. REV. 1083 (1988) [hereinafter Simon, Ethical Discretion].

10. On a recent episode of ER, Dr. Luka Kovac clearly chose to inflict some unnecessary pain on an injured and drunk truck driver, who had just killed a mother and child in a traffic accident, thereby not "doing no harm" as the Hippocratic Oath requires. See ER: Rock, Paper, Scissors (NBC television broadcast, Jan. 11, 2001).

11. In another recent depiction of modern professions, the architect of Once and Again, Rick Sammler, acknowledged during grand jury proceedings that his big project to design a large corporate urban center involved the paying of hribes to inspectors, city officials, and labor unions. See Once and Again: Armageddon Part I (ABC television broadcast, Apr. I1, 2001).

12. Virtually each week of N.Y.P.D. Blue (ABC television broadcast, 1993-current) involves a classic and now formulaic performance of the "prisoner's dilemma" in which two compatriots in crime are separately locked up and coerced into "defecting" against each other by confessing, sometimes after obviously brutal physical force has been applied. See WILLIAM POUNDSTONE, PRISONER'S DILEMMA (1992), for a full description of the game theoretic origins and applications of the prisoner's dilemma.

13. See JOSEPH L. BADARACCO, JR., Defining MOMENTS: When Managers MuSt CHOOSE BETWEen RIGHT AND RIGHT (1997); Lynn Sharp Paine, Moral Thinking in Management: An Essential Capability, in ETHICS IN PRACTICE: LAWYERS' ROLES, RESPONSIBILITIES AND REGULATION (Deborah L. Rhode ed., 2000). See also David Luban, The Ethics of Wrongful Obedience, in ETHICS IN PRACTICE, supra, for a discussion of ethics in large organizations.

14. See KazUo ISHiguro, THE Remains OF THE DaY (1989). Both the novel and the movie, THE Remains OF THE DAY (Columbia Pictures \& TriStar Studios 1993), based on the novel are now commonly taught to raise issues of professional ethics and loyalty to clients of objectionable goals. See, e.g., Rob Atkinson, How the Butler Was Made to Do It: The Perverted Professionalism of The Remains of the Day, 105 YALE L.J. 177 (1995); David Luban, Stevens's Professionalism and Ours, 38 WM. \& MARY L. REV. 297 (1996).

15. See the description of the morality and professionalism of Charles-Henti Sanson, the executioner of Paris who survived and retained his office from the regime of monarchy through the many changes of the French Revolution, in ARTHUR ISAK APPLBAUM, ETHICS FOR AdVERSARIES: THE MORALITY OF ROLES IN PUBLIC AND PROFESSIONAL LIFE (1999).

16. Modern television shows with their weekly installments of lawyer plots, especially when continuing stories are used, are replicating the scrialization of nineteenth century novels. 
focus more on acts and discrete plot turns rather than on character. Thus, the multiplicity of ways in which lawyers are represented allow us to create a sociologist's "four-fold table." 17 We can examine and map examples of expressions of legal ethics or morality demonstrated in popular culture, considering lawyers' characters and acts in positive and negative columns, representing both professional and personal choices. ${ }^{18} 1$ supply some examples in the following chart:

\begin{tabular}{|l|l|l|}
\hline Lawyer's: & \multicolumn{1}{|c|}{+} \\
\hline Act-Professional & Taking Unpopular Client & Lying, Deception \\
\hline Act-Personal & Caring for Someone & Lying, Cruelty, Adultery \\
\hline Character-Professional & Mentoring, Integrity & Manipulation, Greed \\
\hline Character-Personal & Kindness, Commitment & Selfishness, Deceit \\
\hline
\end{tabular}

Longer treatments of lawyers' actions in serialized television shows and longer novels allow more panoramic, less "snapshotted" pictures of lawyers to be painted, than in movies or short stories, which, in turn, can be used effectively to highlight particular decisions. ${ }^{20}$ Depictions of lawyers' actions

Just as with most of Charles Dickens's novels, hungry consumers of the stories anxiously await the latest plot turns or characterizations.

17. The "four-fold table" represents the distribution of two bivariate variables. In the text, 1 have actually created a more complex table to reflect the multidimensional way in which we might consider lawyers' characters and acts in both their professional and personal lives.

18. The relationship of a lawyer's personal life to his or her professional responsibility or legal ethics is a complex subject that I explored in Carrie Menkel-Meadow, Private Lives and Professional Responsibilities? The Relationship of Personal Morality to Lawyering and Professional Ethics, 21 PACE L. REV. 365 (2001). See also Deborah L. Rhode, Moral Character as a Professional Credential, 94 YALE L.J. 491 (1985).

19. For example, what duty of care did the narrator-lawyer owe his clerk, Bartleby the Scrivener, when the latter "preferred not" to work or leave his office? See HERMAN MELVILLE, BARTLEBY THE SCRIVENER: A STORY OF WALL STREET (1853); see also Brook Thomas, "Bartleby the Scrivener": Fellow Servants and Free Agents on Wall Street, in Cross EXAMINATIONS OF LAW AND LITERATURE: COOPER, HAWTHORNE, STOWE AND MELVILLE (1987); Robin West, Invisible Victims: A Comparison of Susan Glaspell's Jury of Her Peers, and Herman Melville's Bartleby the Scrivener, 8 CARDOZO STUD. L. \& LITERATURE 203 (1996).

20. Indeed, at least two lawyer-writers of short "stories" have used actual or slightly fictionalized story forms in order to explicitly highlight the dilemmas of ethical choices made in lawyering. See, e.g., LAWRENCE J. FOX, LEGAL TENDER: A LAWYER'S GUIDE TO HANDLING PROFESSIONAL DILEMMAS (1995); JAMES L. KELLEY, LAWYERS CROSSING LINES: NINE STORIES (2001). See also the fictionalized literary stories about lawyers in LAWRENCE JOSEPH, LAWYERLAND (1997) and the many legal short stories of Louis Auchincloss, discussed more fully in the text. See, e.g., LOUIS AUCHINCLOSS, THE ATONEMENT AND OTHER STORIES (1997); LOUIS AUCHINCLOSS, DIARY OF A YUPPIE (1986) [hereinafter AUCHINCLOSS, DIARY OF A 
in novels, movies, and television shows allow us to view (from multiple "sight-lines") the beginning of the action (what led up to a particular choice point), the action itself, and the consequences of such actions. Thus we are provided multiple ways of seeing (backward, sideways, and forward) the consequences of a lawyer's action, which are often missing from an appellate case as read in the conventional professional responsibility class. ${ }^{21}$

Responses to my opening questions above have included such conflicting descriptions of good lawyers as smart, winning, self-sacrificing, analytic, compassionate; problem-solving, honest, independent, loyal, defenders of unpopular causes/clients, tough, caring, incisive, sensitive, strong, firm, flexible, creative, and justice-seeking. Descriptions of bad lawyers have included such attributes as dishonest, greedy, manipulative, mean, selfish, crafty, wily, disloyal, conforming, adversarial, argumentative, naysaying, negative, fee-focused, and rapacious, among others.

When asked to provide concrete examples or illustrations of these attributes, it is remarkable how many readers or viewers consistently name Atticus Finch, Sir Thomas More, Clarence Darrow (both as a real and as an imaginatively presented character), ${ }^{22}$ Perry Mason, ${ }^{23}$ or E.G. Marshall in The Defenders as emblematic of the good qualities, but any number of John Grisham's characters or Al Pacino's character in The Devil's Advocate ${ }^{24}$ as evil. But, what are we to make of Rusty Sabich in Presumed Innocent, ${ }^{25}$ a good prosecutor, prosecuted for murder because of his adulterous relationship

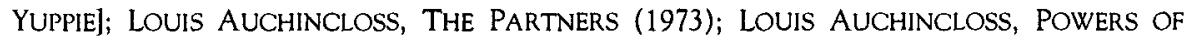
ATTORNEY (1963); see also William Domnarski, Trouble in Paradise: Wall Street Lawyers and the Fiction of Louis Auchincloss, 12 J. CONTEMP. L. 243 (1987).

21. See my argument for the particular usefulness of stories (both real, as in clinical cases, and fictional) in teaching legal ethics in Menkel-Meadow, Telling Stories, supra note 1. See also ROBERT COlE, THE CALl OF STORIES: TEACHING AND THE MORAl IMAGINATION (1989); LAW STORIES (Gary Bellow and Martha Minow eds., 1996). And, for stories about lawyers' ethics and the search for legal justice, told by those who are acted upon in the law (clients and other "outsiders" to law), see PATRICIA EWICK \& SUSAN S. SILBEY, THE COMMON PLACE OF LAW: STORIES FROM EVERYDAY LIFE (1998), which reports on an empirical study of how laypeople view the law and lawyers, and OUTSIDE THE LAW: NARRATIVES OF JUSTICE IN AMERICA (Susan Richards \& Porter Shreve eds., 1997).

22. As demonstrated in both the play, JEROME LAWRENCE \& ROBERT E. LEE, INHERIT THE WIND (Dramatists Play Service, Inc. ed. 1963), and movie INHERIT THE WIND (United Artists 1960), the movie COMPULSION (20th Century Fox 1959) (portraying Darrow's defense of Leopold and Loeb), as well as in his biographies, see ATTORNEY OF THE DAMNED: CLARENCE DARROW IN THE COURTROOM (Arthur Weinberg ed., 1989). See also MILNER S. BALL, THE WORD AND THE LAW 61 (1993), for a discussion of Clarence Darrow's inspirational force among public-interestminded lawyers.

23. See Perry Mason (CBS television broadcast, 1957-1966).

24. THE DEVIL'S ADVOCATE (Warner Bros. 1997).

25. SCOTT TUROW, PRESUMED INNOCENT (1987). 
with a coworker. Or Michael Brock of John Grisham's The Street Lawyer, who begins as a greedy partnership-seeking lawyer in a major Washington D.C. firm and ends as a lawyer for the homeless? Or Bobby Donnell in The Practice, ${ }^{27}$ who defends both the guilty and the innocent, using a variety of tactics, including skillful cross-examinations and questionable tactics like "Plan B" (falsely suggesting someone else did it) $?^{28}$ As character and concrete acts of professional and personal life are depicted over time and in settings increasingly more diverse than the dramatic courtroom, these modern protagonists in popular culture often present a more complex and nuanced picture of the modern lawyer, neither all heroic nor all evil.

In this Essay, 1 want to explore a few examples of depictions of lawyers in popular culture to suggest that modern lawyers demonstrate a full range of moral and ethical behavior, both personally and professionally, and that these depictions of lawyers in popular culture are actually extremely effective exemplars of legal ethics from which we can teach and learn much. 1 am particularly interested in contrasting lawyers' characters or macroprofessional choices (deciding what kind of law to practice, what clients to choose, how to live one's life) with their particular actions or microbehavioral choices (as consumers of popular legal culture learn to ask, when viewing or reading lawyer stories, "Can they do that?").

At least one other teacher of professional responsibility has already developed a full course of legal ethics, by asking his students to systematically explore the ethical dilemmas presented on The Practice. ${ }^{29}$ And, in a new and emerging genre, what I call "bill and tell". stories, ${ }^{30}$ real lawyers, mostly

26. JOHN GRISHAM, THE STREeT LAWYER (1998) [hereinafter GRISHAM, THE STREET LAWYER].

27. The Practice, supra note 9.

28. An interesting twist on the Perry Mason trope, where someone else usually did do itrevealed at the end, following an incisive cross-examination by Perry Mason.

29. See Steven Goldberg, Bringing The Practice to the Classroom: An Approach to the Professionalism Problem, 50 J. LEGAL EDUC. 414 (2000).

30. See, e.g., Paul M. Barrett, THe GoOd Black: A TRue Story of Race iN AMERICA (1999); DAVID HEILBRONER, ROUGH JUSTICE; DAYS AND NIGHTS OF A YOUNG D.A. (1990); William R. Keates, Proceed with Caution: A Diary of a First Year at ONe of America's Most Prestiglous law Firms (1997); Cameron Stracher, Double Billing (1998); see also LinCOln CAPlan, SKadden: Power, MONeY, and tHe Rise of a Legal EMPIRE (1993) (depicting a biography of a law firm); EDGAR JONES, MR. ARBITRATOR (2000) (describing a fictional chronicle of the author's real-life arbitration experience, displaying decision making in real cases, law school cases and family issues). Professor Ted Jones, now retired from UCLA School of Law, taught labor and arbitration law from 1951-1991 and made his own contributions to law and popular culture by appearing as the judge in several $A B C$ fictionalized court programs (Accused (ABC television broadcast, 1958-1959); Day in Court (ABC television broadcast, 1958-1965); Traffic Court (ABC television bróadcast, 1958-1959)), all of which predated People's Court (nationally syndicated television broadcast, 1981-1993) and the new "reality television." Unlike the angrier "bill and tell" stories of the younger generation, Professor Jones seeks 
who have left the practice, tell stories (some fictionalized, some real) of their actual practices that provide deeply contextualized and literal, as well as literary, accounts of their ethical choices.

Finally, by comparing depictions of lawyers' ethical dilemmas to those of other professionals and other workers, we can ask why lawyers are expected to be ethical within their professional rules and why lay consumers of popular culture are permitted to judge them by more than their own professional constraints. ${ }^{31}$

\section{OF CHARACTERS AND ACTS}

Moral philosophers have long debated the subject of whether the morality of a person (or a professional) is to be judged by that person's character or by the concrete acts that he or she commits. ${ }^{32}$ The study of professional ethics has also concerned itself with whether particular roles, such

to model ethical behavior and to teach love of the law, the development of personal integrity, and self-discipline. Mr. Arbitrator reminds us of the now republished first entry into this genre, ARTHUR TRAIN, YANKEE LAWYER: THE AUTOBIOGRAPHY OF EPHRAIM TUTT (1999), a fictionalized series of stories based on Train's own experience, which his son describes as that of a "foxy, kindly, courtly, old-fashioned lawyer who treasures justice for the unfortunate above the letter of the law." John Train, Introduction to the Common Reader, in TRAIN, supra, at $\mathrm{x}$; see also Francis M. Nevins, Mr. Tutt's Jurisprudential Journey: The Stories of Arthur Train, 19 LEGAL STUD. F. 57 (1995); Philip H. DeTurk, The Tutt Stories: A Review, WASH. ST. B. NEWS, Oct. 1991, at 19.

31. The question of whether a good lawyer can be a good person and whether we may judge lawyers by ordinary "personal" morality, rather than solely by "role morality" has been with us for much of modern legal scholarship on lawyer's ethics. See, e.g., THE GOOD LAWYER: LAWYERS' ROLES AND LAWYERS' ETHICS (David Luban ed., 1983); Stephen L. Pepper, The Lawyer's Amoral Ethical Role: A Defense, a Problem, and Some Possibilities, 1986 AM. B. FOUND. RES. J. 613; Gerald J. Postema, Moral Responsibility in Professional Ethics, 55 N.Y.U. L. REv. 63 (1980); Abbe Smith, Can You Be a Good Person and a Good Prosecutor?, 14 GEO. J. Legal ETHICS 355 (2001); Richard Wasserstrom, Roles and Morality, in THE GOOD LAWYER, supra.

32. See, e.g., Alasdair MacinTYRe, The Virtues, the Unity of a Human Life and the Concept of a Tradition, in AFTER VIRTUE (2d ed. 1984) (contrasting "the unity of a human life" as more than a series of "unconnected episodes" or role enactments or "single actions"); see also JUDITH N. SHKLAR, Bad Characters for Good Liberals, in ORDINARY VICES (1984) (discussing Aristotelian and Kantian conceptions of good character as avoidance of vice or pursuit of the good); BeRnard WILliams, Persons, Character and Morality, in MORal LuCK: PHILOSOPHICAL PAPERS 1973-1980 (1981); Virginia Held, The Division of Moral Labor and the Role of the Lawyer, in THE GOOD LAWYER, supra note 31, at 60 (addressing the question of whether or not the unity of professional role morality suggests specific ways to judge acts within the context of a particularized role and not according to the usual "virtues" attributed to Aristotelian concepts of the good person); Bernard Williams, Professional Morality and Its Dispositions, in THE GOOD LAWYER, supra note 31, at 259; Susan Wolf, Ethics, Legal Ethics and the Ethics of Law, in THE GOOD LAWYER, supra note 31, at 38. For these philosophers and others, "what we look for both in public officials and in friends is character. Not a set of discrete heroic, ethically significant decisions, but the imperceptible choices of dispositions that are manifest in the course of a lifetime." Shklar, supra, at 243. 
as soldiers, doctors, lawyers, or butlers provide a role-differentiated set of moral or ethical expectations. In one sense, this can be seen as a conflict of disciplines. Philosophers are more likely to expect virtues of the person, as expressed in "dispositions" in a person's character that are enacted in various situations throughout a person's life. ${ }^{33}$ Sociologists, beginning with the work of Emile Durkheim, ${ }^{34}$ have acknowledged first, the division of labor and then, the moral division of labor by roles in our society, leading to organic order and social functioning.

Some of the recent debates in legal ethics scholarship reenact debates of the 1950s functional-structuralists with the post-Watergate 1970s demands to revisit both personal and professional moral character. ${ }^{35}$ These issues have also recently been revived during the impeachment debates, as we considered whether particular bad "acts" constituted "high crimes or misdemeanors" within a role-differentiated functionality, when what was most disturbing to most people was really the former president's "character" flaws. 36

William Simon's persistent arguments for allowing ethical discretion in lawyer decision making ${ }^{37}$ suggest that lawyers must develop ethical dispositions by exercising judgment with well-internalized values and prudent exercise of both rationality and human care for others (including clients and those in relationship to clients) in increasingly complex contexts, rather than respond mechanistically, like Oliver Wendell Holmes's "bad man," to the "authoritarian and categorical" letter of the code of the

33. For two useful and sometimes amusing applications of these philosophical principles to the living of everyday life, see JOSHUA HALBERSTAM, EVERYDAY ETHICS: INSPIRED SOLUTIONS tO REAL-LIFE DilemMas (1993), and JOHN SABINI \& MaUry Silver, MORALITIES OF EVERYdAY LifE (1982), See also ROBERT NOzICK, THE EXAMINED LIFE: PHILOSOPHICAL MEDITATIONS (1989), for a more serious philosophical look at everyday ethical dilemmas. The novelist Alain de Botton has recently attempted to apply the teachings of serious philosophers to everyday life as well. See ALAIN DE BOTTON, THE CONSOLATIONS OF PHILOSOPHY (2000).

34. See, e.g., EMILE DurkHEIM, Professional ETHICS AND CIVIL MORAlS (Cornelia Brookfield trans., 1992).

35. Following the Watergate crisis, the American Bar Association made professional responsibility a required course for all law students in 1975 on the belief that ethics instruction would improve lawyers' characters, and, at the very least, apprise them of the formal rules for which they might be disciplined.

36. As popular culture now has to take its truth-is-stranger-than-fiction scripts from reallife, recent episodes of The West Wing are exploring whether the president and his wife's statements about his health (he has multiple sclerosis, which was not disclosed to the public who elected him) are serious and impeachable offenses. See The West Wing: Bad Moon Rising (NBC television broadcast, Apr. 25, 2001); The West Wing: 17 People (NBC television broadcast, Apr. 4, 2001). See also the recent novelizations based on President Clinton's scandalous behavior: JOE ESTERHAUS, AMERICAN RHAPSODY (2000), and ERIK TARLOFF, FACE-TIME (1998).

37. See Simon, Ethical Discretion, supra note 9.

38. Simon, Moral Pluck, supra note 9 , at 423. 
Model Rules. Thus, Simon, like other realist "contextualists, ${ }^{39}$ finds value in the highly contextualized stories of modern popular culture that depict lawyers demonstrating their "moral pluck," in actions which he defines as "transgressive and resourceful." "Lawyers take such action when they have to choose courses of action that require independent thinking, when rules are too rigid, contradictory, ambiguous, or non-existent.

Kantian-like moralists, ${ }^{41}$ who would impose categorical ethical imperatives, particularly having to do with character or absolute rules ${ }^{42}$ ""thou shalt never lie"), or those who believe that positive rules and laws can and should provide adequate guidance for the ethical lawyer, ${ }^{43}$ are opposed to the more discretionary form of ethical decision making suggested by some legal ethicists.

The claim that stories, with their non-universal contexts and particular "truths" are the best way to teach about good character (through illustration), good decision making, and action (through empathic understanding) is hardly new. Philosophers and literary critics have made such claims for years, and law professors have joined the argument. ${ }^{44}$ James Boyd White is

39. See David B. Wilkins, Legal Realism for Lawyers, I04 HARV. L. REV. 468 (1990). I count myself among the realist contextualists, having spent the last five years drafting ethics rules and best practices for lawyers in a particular context-that of third party neutrals, in which "ordinary" and categorical rules about advocacy are inapposite. See Carrie Menkel-Meadow, Ethics and Professionalism in Non-Adversarial Lawyering, 27 FLA. ST. L. REV. 153 (1999); Carrie MenkelMeadow, The Silences of the Restatement of the Law Governing Lawyers: Lawyering as Only Adversary Practice, 10 GEO. J. LEGAL ETHICS 631 (I997).

40. Simon, Moral Pluck, supra note 9, at 422.

41. See Immanuel Kant, Grounding For the Metaphysics of MORAls (James W. Ellington trans., 198I).

42. See, e.g., William J. BennetT, The BOOK OF Virtues: A TREasury of Great MORAL STORIES (I993).

43. See, e.g., GeOfFrey C. Hazard, JR. \& W. WILliam HOdES, THE LAW OF LAWYERING: A HANDBOOK ON THE MODEL RULES OF PROFESSIONAL CONDUCT (2d ed. 1990); Geoffrey C. Hazard, Jr., Law Practice and the Limits of Moral Philosophy, in ETHICS IN PRACTICE, supra note 13, at 76 (associating himself with the "situated" ethics school in denouncing the ability of philosophical "universals" to give adequate guidance to lawyers who are making ethical choices in "real-world, not hypothetical situations"); Geoffrey C. Hazard, Jr., Legal Ethics: Legal Rules and Professional Aspirations, 30 CLEV. ST. L. REV. 571 (I982).

44. See, e.g., MARIA ARISTODEMOU, Language Ethics and the Imagination in Toni Morrison's Beloved, in LAW \& LITERATURE: JOURNEYS FROM HERE TO ETERNITY (2000); WAYNE C. BOOTH, THE COMPANY WE KEEP: THE ETHICS OF FICTION (1988); JOHN GARDNER, ON MORAL FICTION (1978); MARTHA NUSSBAUM, POETIC JUSTICE: THE LITERARY IMAGINATION AND THE PUBLIC LIFE (1995); RICHARD A. POSNER, The Edifying School of Legal Scholarship, in LAW AND LITERATURE: A MISUNDERSTOOD RELATION (rev. ed. 1998); LEO TOLSTOY, WHAT IS ART? (Richard Pevear \& Larissa Volokokhonsky trans., 1995); RICHARD H. WEISBERG, THE FAILURE OF THE WORD: THE PROTAGONIST AS LAWYER IN MODERN FICTION (1984); RICHARD H. Weisberg, POETHICS: AND OTHER STRATEGIES OF LAW AND LiteratURe (1992); ROBIN WeST, CARING FOR JUSTICE (1998); Robin West, Law and Fancy, 95 MICH. L. REV. 1851 (1997) (reviewing Nussbaum); James Boyd White, Acts of Hope: Creating Authority, in LITERATURE, LAW 
the father of a "law and literature" movement, which suggests that it is only through study of the humanities side of law that a lawyer can become fully human. "Use of "high" literature (Greek myths, philosophy, ${ }^{46}$ classical plays, the "great novels," and selected short stories) to teach about professional and even legal ethics has become quite common. But, as the examples below will illustrate, it is probably the more commonly viewed movies and television shows and the more commonly read popular novels that instill legal ethical curiosity in the modern-day law student and that carry some penetrating lessons for the practicing lawyer.

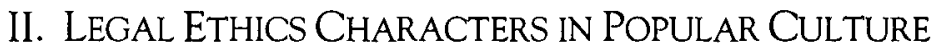

If Atticus Finch, Sir Thomas More, and Clarence Darrow represent, in both fiction and fact, the pinnacle of lawyer character, it is useful to examine what about their characters makes them exemplary. If there is one quality that unites lawyer heroes, it is their commitment to principle(s), and often to causes and people that represent "justice" to them, usually at some great personal risk. We honor those lawyers who seek to serve the ends of justice (law is only the means ${ }^{47}$ ) by representing unpopular clients, by seeking justice in the form of equality for the subordinated or dispossessed,

AND POLITICS (1994); cf. Jane B. Baron, Law, Literature, and the Problems of Interdisciplinarity, 108 YALE L.J. 1059 (1999) (suggesting we can misread literature as a lesson for legal interpretation and legal ethics when we fail to recognize the limits of interdisciplinary study).

45. See, e.g., JAMES BOYD WHITE, JUSTICE AS TRANSLATION: AN ESSAY IN CULTURAL AND LEGAL CRITICISM (1990); JAMES BOYD WhITE, From EXPECTATION TO EXPERIENCE: ESSAYS ON LAW AND LEGAL EDUCATION (1999); see also ROBIN WEST, NARRATIVE, AUTHORITY AND LAW (1993). The literary critic and historian Robert Ferguson has argued that in our country's formative years, lawyers were more well-rounded humanists in their characters because the study of classical literature (as well as literary authorship) characterized both good legal education and the character of a good lawyer. See ROBERT A. FERGUSON, LAw AND LETTERS IN AMERICAN CULTURE (1984).

46. For example, a number of us have been teaching PLATO, GORGIAS (Walter Hamilton trans., 1960) (380 B.C.) as an argument about professional ethics (the ethics of the Greek orator and teacher of rhetoric, likened to that of the advocate). See, e.g., HOWARD LESNICK, BEING A LAWYER 29-33 (1992); James Boyd White, The Ethics of Argument: Plato's Gorgias and the Modern Lawyer, 50 U. CHI. L. REV. 849 (1983).

47. "Justice is the end, law is the means" is a quote found on the Edward Bennett Williams Law Library at Georgetown University Law Center, attributed to a former student. Many of the lawyers we find exemplary in literature, if not in life, are those who serve justice in spite of, not because of, the law. Sir Thomas More represents the appeal to a "higher law," whether God's "natural law," or a higher principle than the instrumentally created law of Henry V11l (seeking to justify his divorce from his wife Mary) or of the Catholic Church. Like Sir Thomas More, Antigone represents a character who rejects state law in seeking a different kind of justice, whether considered religious, familial, "natural," or personal. See SOPHOCLES, ANTIGONE (Dover Thrift ed. 1993) (442 B.C.); see also JEAN ANOUILH, ANTIGONE (Barbara Bray trans., 2001); JUDITH BUTLER, ANTIGONE'S CLAIMS: KINSHIP BETWEEN LIFE \& DEATH (2000). 
by seeking vindication for the wrongfully accused, by obtaining compensation for the wrongfully injured, or representing a larger social principle (such as Darrow's defense of the teaching of evolution in the Scopes trial).

Note that heroic lawyers sometimes, not always, seek the truth (that is the "honor" of scientists and academics). Justice occasionally requires an untruthful turn. The ironies of many stories about lawyers is that a lawyer seeking justice must occasionally trample on the truth or on an ethical rule to get there (as in the transgressions of several of John Grisham's youthful heroes on their way to unmasking the greed or evil of either other lawyers or bad corporate forces). ${ }^{48}$

And, like many real heroes, ${ }^{49}$ good lawyers are devoted to their professional causes and sometimes neglect families or have unfullfilling personal lives. Atticus Finch serves as a model-if sometimes harsh-father. But he is a widower, who has to "soldier on" alone,$^{50}$ and in the end, he too, agrees to lie in order to do a more perfect justice. ${ }^{51}$ Sir Thomas More lost his life and his devoted family in the name of a principle.

And heroes do lose. Clarence Darrow was known to lose a few cases. Even our heroes are not perfect. (Perry Mason lost three cases during the run of the television version of Erle Stanley Gardner's creation, and, after some complaints that the prosecutors were always winning on Law $\mathbb{E}$ Order, ${ }^{52}$ even that star prosecutorial team lost a few cases). As David Papke has suggested ${ }^{53}$ The Defenders has been regarded as "heroic," because of its courageousness in taking on the social issues of the day, including civil lib-

48. See JOHN GRISHAM, THE FIRM (1991) ]hereinafter GRISHAM, THE FIRM], JOHN Grisham, THE PEliCAN BRIEF (1992), JOHN GRISHAM, THE RAINMAKER (1995) [hereinafter GRISHAM, THE RAINMAKER], and GRISHAM, THE STREET LAWYER, supra note 26, as examples.

49. Biographers have chronicled the less than exemplary personal lives of such heroes as Mahatma Gandhi, see ERIK H. ERIKSON, GANDHI'S TRUTH: ON THE ORIGINS OF MILITANT NON-VIOLENCE (1969), Martin Luther King, Jr., see DAVID J. GARROW, BEARING THE Cross: MARTIN LUTHER KING, JR. AND THE SOUTHERN CHRISTIAN LEADERSHIP CONFERENCE (1986), and John F. Kennedy, see SeYmour M. HerSH, THE DARK Side Of CAMELOT (1997).

50. Sam Waterston's character in the remarkable series I'll Fly Away, Forrest Bedford, is at least partially based on Atticus Finch, a widower raising three children and struggling with the nascent civil rights movement in the South, as he watches his familiar community change around him. Unlike Finch, he is also able to see somewhat closer at hand the effects of racism in his community by watching the growing political activism of his maid, Lily, while he takes on the role of prosecuting civil rights violators as the district attorney (not criminal defense attorney). See I'll Fly Away (NBC television broadcast, 1991-1993).

51. By changing the reported facts surrounding the murder committed by Boo Radley at the end of the story, a chastened Atticus Finch begins to have some doubts about the absolute justice of the rule of law when measured against humane and retributive justice. See Lubet, supra note 7 .

52. Law \& Order (NBC television broadcast, 1990-current).

53. See Papke, supra note 6. 
erties, racism, abortion, the death penalty, and conscientious objection, especially when compared to Perry Mason, which was still on the air when The Defenders began. In one sense this social critique function is now played by The Practice, in contrast to L.A. Law, ${ }^{54}$ both written by David E. Kelley, as the former addresses difficult social and legal issues (assisted suicide, date rape, criminal environmental hazards), along with a steady diet of murders and drug deals, while L.A. Law tended to feature up-scale divorce, high-end products liability cases, and tax law, with a few pro bono cases handled by Ann Kelsey (she also raised a few issues about women in the Iaw)..$^{55}$ Today's stories of lawyers with "character" show them as more flawed and also as likely to lose some cases (more realistic portrayals I believe), but the good lawyer is resilient and most importantly committed.

It seems somewhat odd to me and consistent with those who have chronicled the more negative depiction of modern lawyers in the media that one of the only recent "lawyers as hero" in popular fiction is Michael Brock of The Street Lawyer. ${ }^{56}$ Although Grisham is not known for deep character development, Michael Brock demonstrates character change. He begins as a greedy, selfish, overly busy, and ambitious associate, but becomes a lawyer for the homeless after being taken hostage and confronting the excesses of his life in a world of privilege. Grisham uses all the devices of traditional thrillers and mysteries to work a plot that has Brock exposing his former law firm as a nasty organ of unlawful evictions in the name of corporate real estate development. ${ }^{57}$

The Street Lawyer also demonstrates another modern turn on the hero's character. Real heroes in modern legal stories are often not lawyers, but paralegals or legal secretaries, close to, but not of, the legal profession. The paralegals Sofia Mendoza (who works in the homeless clinic) and Hector Palma (the big firm paralegal who steals files to right the wrongs his firm has committed) are more committed to justice, people, and causes than are most of the lawyers around them (with the exception of Mordecai Green, the hardworking founder of the homeless clinic). Like the recent depiction of Erin Brockovich, ${ }^{58}$ a paralegal who almost single-handedly takes on the corporate water polluters, these paralegals suggest that not enough lawyers are available to work for "the little people," when everyone seems to be

54. L.A. Law (NBC television broadcast, 1986-1994).

55. See John Brigham, L.A. Law, in PRIME TIME LAw, supra note 6; see also Christine Alice Corcos, Women Lawyers, in PRIME TIME LAW, supra note 6.

56. GRISHAM, THE STREET LAWYER, supra note 26.

57. Why is it that, at least as of this writing, this is one of Grisham's books that has not been filmed? Homelessness is not as cinematic as extortion, deaths of supreme court justices, law firm fraud, and covered-up civil rights violations.

58. ERIN BROCKOVICH (Jersey Films 2000). 
chasing those L.A. Law dollars. These days, only those outside of the profession seem to take on the unpopular cases or the dispossessed and injured.

On the other hand, as modern literature has moved from fiction to memoir, we find our lawyer-heroes these days more frequently in different forms of popular culture-the legal memoir or journalistic account of the actual case. Starting perhaps with The Buffalo Creek Disaster ${ }^{59}$ and culminating with the recent bestseller success of a journalist's reporting of Jan Schlichtmann's role in A Civil Action, ${ }^{60}$ lawyers seem to need to tell their own stories of commitment to causes (mass torts, corporate misfeasance, serious death, and illness) and to people, whereas the fiction and film worlds have taken a more cynical turn. Books like The Buffalo Creek Disaster and A Civil Action ${ }^{61}$ often document character changes not unlike that of Michael Brock, as in Gerald Stern's commitment of time, labor, and money to a complicated public interest case from within the comfort of his large Washington D.C. law firm, or Jan Schlichtmann's literal "betting the firm" on his fight for people with leukemia caused by toxic dumping in the Woburn water supply. These men, like the transformed hero of Schindler's $\mathrm{List}^{62}{ }^{62}$ are ordinary men, working either within corporate privilege or in traditional small law firm struggles, but they are "moved" by their work to commit their professional lives, money, and often, their personal lives to people and causes outside of their usual ken.

Perhaps one of the richest explorations of modern-day legal heroes can be found in the non-fiction reportage of Melissa Fay Greene in Praying for Sheetrock, ${ }^{63}$ in which a group of dedicated legal services lawyers help a black community gain political power in a southern town marked by decades of white rule, through the filing of lawsuits and the use of political action. Her story demonstrates that the real unsung heroes of lawyering are those

59. Gerald M. Stern, THe Buffalo Creek Disaster (1976).

60. Jonathan HaRr, A Civil ACTION (1995); A Civil ACTION (Paramount Pictures et al. 1998).

61. These are not the only such popular culture books about particular legal struggles that reveal the character of lawyers. PAUL BRODEUR, OUTRAGEOUS MISCONDUCT (1985) chronicles the work of worker's compensation lawyers who champion the asbestos cause (and become wealthy in the process). Richard B. Sobol tells a similar tale for the plaintiffs' lawyers in the Dalkon Shield case, in RICHARD B. SOBOL, BENDING THE LAW (1991). Several books have attempted the tale of the persistent plaintiffs' lawyers in the tobacco wars, see, for example, DAVID KESSLER, A QUESTION OF INTENT: A GREAT AMERICAN BATTLE WITH A DEADLY INDUSTRY (2001), and DAN ZeGART, CIVIL WARRIORS: THE LeGAL SIEGE ON THE TOBACCO 1NDUSTRY (2000). See the movie THE INSIDER (Buena Vista Pictures 1999) for the story of a nonlegal whistle blower. For another form of hero depicted in modern popular culture, see also SilKwOOD (20th Century Fox 1983), as inside workers reveal facts to lawyers and the press that corporate lawyers and actors sought to hide.

62. THOMAS KeNEALLY, SCHINDLER'S LIST (1994).

63. MELISSA FAY GREENE, PRA YING FOR SHEETROCK (1991). 
who labor with little pay and much commitment to cases and people who seldom gain the attention of klieg lights. ${ }^{64}$

Modern-day heroes are crafted in a more complex world, where there is more than the local community and the self to serve. More often than not, the better treatments of "character" in popular culture demonstrate change or redemption ${ }^{65}$ of the lawyer character. Michael Brock becomes a street lawyer after being taken hostage and losing a wife who, as a doctor, also worked long, hard, relationship-killing hours, and realizes that he could be employing his considerable legal skills in more fulfilling ways. Frank Galvin, the drunken "anti-hero" of The Verdict ${ }^{66}$ finds salvation, redemption and recovery of his personhood and professional career by becoming committed to his comatose medical malpractice client and by fighting off a large and somewhat unscrupulous law firm (even though Galvin is also not above bending a few ethical rules).

For these more complicated characters, who are neither all good nor all bad, character is constituted in the complex relationship of personality and circumstance. While being a lawyer tempts one to do everything for a client (including pushing over the line of permissible legal ethics), or to do everything for oneself and for personal aggrandizement, being a lawyer also offers one the opportunity to respond to. legal or personal challenges and to recommit to the justice-based values of the profession. Redemption is possible for lawyers who find meaning in serving others and in rediscovering the value of their professional selves.

As Robert Coles has recently demonstrated in Lives of Moral Leadership, ${ }^{67}$ today's hero must be effective and must act; it is not enough to be idealistic and to care about justice or good causes. Thus, the lawyers who re-find their efficacy by accomplishing something-a career change (Michael Brock), the ability to work hard and win a case again (Frank Galvin), or the courage to keep representing unpopular clients (Bobby Donnell and Eugene Young on The Practice) after "tests" of their modern mettle-seem to represent our own version of the more modest Greek drama of professionalism.

64. See Carrie Menkel-Meadow, The Causes of Cause Lawyering: Toward an Understanding of the Motivation and Commitment of Social Justice Lawyers, in CAUSE LAWYERING: POLITICAL COMMITMENTS AND PROFESSIONAL RESPONSIBILITIES 31 (Austin Sarat \& Stuart Scheingold eds., 1998).

65. See Paul Bergman, The Movie Lawyers' Guide to Redemptive Legal Pratice, 48 UCLA L. REV. _ (2001).

66. THE VERDICT (20th Century Fox 1982).

67. ROBERT COLES, LIVES OF MORAL LEADERSHIP (2000) (suggesting that good character requires the ability to get things done, as he chronicles Martin Luther King's ability to mobilize people and effectuate civil actions of a different, not legal, sort, and Robert Kennedy's political shrewdness in passing important legislation targeted to reduce child hunger and poverty). 
Another element of modern character development is significant to note- the recognition of small worlds of professional communities. Many of the earlier depictions of modern heroes focus on the strength, courage, redemption, or recovery of the individual lawyer. But, there are also interesting depictions of some of the lawyers' commitments to each other and to the professional communities they create. Over thirty years ago, one commentator noted the creation of "professional communities" on a variety of the early lawyer and doctor television programs, in which lawyers help and succor each other while performing difficult, but important, public service. ${ }^{68}$ Many of the dramatizations of professionals on television in the "golden era" of the 1950s and $1960 \mathrm{~s}^{69}$ involved character development in the training and mentoring of a younger professional by an older and wiser professional-the senior Lawrence Preston (The Defenders) guiding his son, Kenneth, Dr. Gillespie and Dr. Kildare (Dr. Kildare ${ }^{70}$ ), Dr. Zorba and Ben Casey (Ben Casey ${ }^{71}$ ), now replicated in Leland McKenzie on L.A. Law, and an only slightly older, but clearly more experienced, Bobby Donnell on The Practice. Gene Hackman's father figure does much the same to turn his daughter, big-firm defender of corporate interests, into a lawyer also seeking social justice in Class Action. ${ }^{72}$ These "learning communities" of lawyers (and other professionals) demonstrate that being a professional does require good character (loyalty, ongoing learning, honesty (at least with one's colleagues, if not the system), and devotion to the larger public and to social good). Hear what one television critic has said of the television professionals of the 1960s and consider how much of it is still true:

$[T]$ hey know that without such work the quality of everyday life would plummet, society would flounder. Their jobs, in short, are the best of all possible jobs: they offer both inner meaning and public worth. Television's city-dwelling professionals thus serve as living proof that work in the modern world can be beautiful.... The professionals of these programs are not only public servants; they are also spokesmen of society, and their behavior reveals the way society operates to take care of its own.... The professionals themselves are tireless, selfless, and profoundly equitable.... In the presumably cold, dead heart of contemporary life and society, television's profes-

68. Harris Dienstrey, Doctors, Lawyers and Other TV Heroes, in 35 COMMENTARY (1963), reprinted in TELEVISION: THE CRITICAL VIEW (Horace Newcomb ed., 1976).

69. Are these years of television now considered "golden" because so many of us of a certain age grew up watching them? At the time television premiered serious cultural critics decried this new medium as "lowering" our cultural standards. See Dienstrey, supra note 68.

70. Dr. Kildare (NBC television broadcast, 1961-1966).

71. Ben Casey (ABC television broadcast, 1961-1966).

72. Class ACTION (20th Century Fox 1991). 
sional dramas have managed to find nothing less than the pulse of the good community. The living there may have its difficulties, admittedly, but in the end the problems are only superficial ones. For this is a place that offers meaningful work, $\left.{ }^{73}\right]$ a public devotion to the common good, and secure, vital values. ${ }^{74}$

More recent professional series demonstrate an even more equalitarian sense of community. Although Leland McKenzie presided over highly fictionalized daily firm meetings, the lawyers of L.A. Law and The Practice, like their compatriots on ER, mostly soldier on together in relative equality and with unrepresentatively little concern about partnerships and hierarchy. Occasionally there are treatments of partnership and income, but these modern-day professionals mostly help each other through their difficult cases. They seem to be more likely to help and to fall in love with each other (which involves all kinds of conflicts of interests that the shows do not portray with much ethical accuracy ${ }^{75}$ ) than to engage in the kind of ruthless competition with each other that is the presumed culture and frequent depiction of legal education. ${ }^{76}$ Indeed, while police detectives have to deal with and often complain about their hierarchical bosses on N.Y.P.D. Blue ${ }^{77}$ and Homicide, ${ }^{78}$ there is little critique of senior partners and much less depiction of ethical conflicts between senior and junior lawyers on television than in the days of "yore," ${ }^{79}$ in real life, ${ }^{80}$ or in other media.

73. See William H. Simon, Ethics, Professionalism and Meaningful Work, 26 HOFSTRA L. REV. 445 (1997), for a different view. Simon argues that much of modern literature portrays lawyers as losing their moral agency (discussing Dickens, Dostoevsky, Kafka, and Melville's lawyers as alienated from role, purpose, and moral agency).

74. Dienstrey, supra note 68 , at $83-85$.

75. Echoing that great classic of romantic conflicts of interest between lawyers is ADAM'S RIB (MGM 1949), starring Spencer Tracy and Katharine Hepburn as spouses on opposite sides of a criminal case.

76. See CHRIS GOODRICH, ANARCHY AND ELEGANCE: CONFESSIONS OF A JOURNALIST AT YALE LAW SCHOOL (1991); RICHARD D. KAHLENBERG, BROKEN CONTRACT: A MEMOIR OF HaRVARD LAW SCHOOL (1992); MiCHaEl LeVIN, THE SOCRATIC METHOD (1987); JOHN JAY OSBORN, THE PAPER CHASE (1972); SCOTT TUROW, ONE L (1977).

77. N.Y.P.D. Blue (ABC television broadcast, 1993-current).

78. Homicide: Life on the Street (NBC television broadcast, 1993-1999).

79. Dramatic moments on The Defenders, Dr. Kildare, and Ben Casey all included instances of mutual learning, when the elder professional learned something from a new kid on the block. See Dienstrey, supra note 68.

80. See, e.g., JAMES StewART, THE PARTNERs: 1NSIDE AMERICA's MOST POWERful LAW FIRMS (1983) (describing the unethical activity of senior partners in the Kodak antitrust litigation); see also Lawrence J. Fox, I'm Just an Associate . . . at a New York Law Firm, 69 FORDHAM L. REV. 939 (2000).

81. My favorite depiction of the changing order of modern legal ethics can be found in AUCHINCLOSS, DIARY OF A YUPPIE, supra note 20, in which the younger, more aggressive Robert Service (in service to his clients) wants to engage in a search of his opponent client's discarded garbage (an "'abandoned property' search," id. at 8 ) in a hostile takeover and his senior partner (a 
Like other reflections of society in popular culture, treatment of professional character mirrors issues in the real world. Following the recent political scandals of the. Bill Clinton presidency, questions about what good character is, and how it relates to professional duty and responsibilities, have been raised in all venues, from the movies to Sunday school to Sunday talk shows. ${ }^{82}$ While The West Wing ${ }^{83}$ ends this season with an exploration of presidential truth telling about arguably private matters with public implications (the president's health), the recent movie The Contender, ${ }^{84}$ took on the relevance of a political figure's sex life to her professional duties. When a seemingly documented scandal accuses vice presidential nominee Laine Hanson of engaging in a college-day fraternity sex orgy, ${ }^{85}$ she refuses to discuss the matter, demonstrating commitment to the principle that whatever she may or may not have done in her youth is irrelevant to her current qualifications to be vice president. The Contender not only cleverly reworks the Clinton ethical and political quandaries, but suggests that professional character may also have gendered dimensions: Laine Hanson's commitment to silence and her refusal to discuss publicly this "private" matter also confronts the question of whether a woman's character in professional life may be judged differently. As the number of women (and other previously excluded demographic groups) increases in media portrayals of lawyers we will have an increased opportunity to explore whether popular culture is ahead, in step with, or behind the reality of the integration of the profession. ${ }^{86}$

representative of a more "gentlemanly," if homogeneous era) chastises him for violating the professional code ("there's no place in my law practice for obscenity," id. at 10).

82. See, e.g., William J. BeNNETT, THE DEATH OF OUTRAGE: BILl Clinton AND THE ASSAULT ON AMERICAN IDEALS: THE INVESTIGATION, IMPEACHMENT, AND TRIAL OF President Clinton (1998); Richard A. POSNer, AN AFFAir of STATE (1999); JeFFrey ToObin, A Vast Conspiracy: The Real Story of the SeX SCandal that Nearly BROUGHT DOWN A PRESIDENT (1999).

83. The West Wing (NBC television broadcast, 1999-current).

84. THE CONTENDER (Battleground Productions 2000).

85. Somewhat presciently "foreshadowing" the disclosure of college-day "youthful indiscretions" of our current President George W. Bush's documented difficulty with alcohol and rumored difficulty with drugs. As I write this, the president's daughter has been arrested for underage drinking, raising further questions about the divisions between private and public life and how wide the ring of responsibility is around certain professional office holders.

86. See Corcos, supra note 55; Louise Everett Graham \& Geraldine Maschio, A False Public Sentiment: Narrative and Visual Images of Women Lauyers in Film, 84 KY. L.J. 1027 (1995-1996); Diane Klein, Ally McBeal and Her Sisters: A Quantitative and Qualitative Analysis of Representations of Women Lawyers on Prime-Time Television, 18 LOY. L.A. ENT. L. REV.. 259 (1998); Carrie Menkel-Meadow, Excluded Voices: New Voices in the Legal Profession Making New Voices in the Law, 42 U. MIAMI L. REV. 29 (1987); Carole Shapiro, Women Lawyers in Celluloid: Why Hollywood Skirts the Truth, 25 U. TOL. L. REV. 955 (1995); Cheryl Smith-Khan, African American Attorneys in Television and Film: Compounding Stereotypes, 22 LEGAL STUD. F. 119 (1998); David B. Wilkins 
Whether the moral character of lawyers is related to who they are personally and demographically is also a fascinating question to examine from the perspective of popular culture, sometimes reflecting, sometimes challenging more scholarly treatments of the same issue. I have argued for years that women may bring a different moral sensibility to the practice of law by seeking to do less harm, solve more problems, be more concerned with human relationships of both clients and of those who interact with clients, and to deal with others more honestly and fairly. ${ }^{87}$

Therefore, it should be no surprise that one of my favorite depictions of the struggles of modern lawyers is the film All of $\mathrm{Me}^{88}$ In this film, which uses a now standard plot of bump-on-the-head transformation into someone else, ${ }^{89}$ Steve Martin, playing a stereotypically aggressive and dishonest lawyer, becomes literally embodied by the soul of Lily Tomlin, a deceased, dogooding woman. In what has to be one of the funniest and most serious critiques of the character of lawyers, Lily Tomlin and Steve Martin literally, figuratively, and linguistically fight over the control of both body and soul of a lawyer who, in Steve Martin's body, makes a dishonest closing argument, as Lily Tomlin struggles to push the truth out of Steve Martin's mouth. (Of course, this scene can be read not only as a gender critique of lying male lawyers, ${ }^{90}$ but as the standard-layperson as moral, lawyer as good professional but bad person-critique found in much moral philosophy. . $^{91}$

On The Practice, Eugene Young's recent defense of his work as a criminal defense lawyer, against his ex-wife's claim that he should not have custody of his young black son who was arrested for possession of drugs in a school locker, courageously depicted these lawyer character issues (commitment to

\& G. Mitu Gulati, Why Are There So Few Blacks in Corporate Law Firms? An Institutional Analysis, 84 CAL. L. ReV. 493 (1996).

87. See, e.g., Carrie Menkel-Meadow, The Feminization of the Legal Profession: The Comparative Sociology of Women Lawyers, in LAWYERS IN SOCIETY: COMPARATIVE THEORIES (Richard L. Abel \& Philip S.C. Lewis eds., 1989); Carrie Menkel-Meadow, Porcia in a Different Voice: Speculations on a Women's Lauryering Process, 1 BERKELEY WOMEN'S L.J. 39 (1985); Carrie Menkel-Meadow, Portia Redux: Another.Look at Gender, Feminism and Legal Ethics, 2 VA. J. Soc. POL'Y \& L. 75 (1994); Carrie Menkel-Meadow, What's Gender Got to Do with It? The Morality and Politics of an Ethics of Care, 22 N.Y.U. ReV. L. \& SOC. CHANGE 265 (1996); Carrie MenkelMeadow, Women's Ways of Knowing Law: Feminist Legal Epistemology, Pedagogy and Jurisprudence, in KNOWLEDGE, DIFFERENCE AND POWER (Nancy Goldberger et al. eds., 1996).

88. ALL OF ME (Universal Pictures 1984).

89. See WHAT WOMEN WANT (Paramount Pictures 2000) as the latest entry in this genre. Mel Gibson's character suddenly is able to hear what goes on inside women's minds.

90. See the even more over-the-top and explicit critique of lawyers as liars in Jim Carrey's LIAR LIAR (Universal Pictures 1997).

91. See supra note 31 . 
justice and equal treatment) with the added social dimension of race. ${ }^{92}$ Eugene's defense of his profession and its purpose is, in my mind, the most eloquent defense of the criminal defense lawyer's calling and commitment to justice seen in the popular media in decades.

Perhaps the most troubling of lawyer character issues depicted in the popular media, which replicates the debates among legal philosophers and ethicists, is the tension, in a lawyer of good character, between commitment to law and commitment to justice. As Americans and lawyers, we argue throughout the world for the sanctity, as well as the instrumental fairness, of the rule of law. Some legal ethicists seek clarity and conformity in the "law of lawyering.".93 Writers of popular fiction, movies, and television mirror the challenge that William Simon and others have posed to the law of legal ethics. Consider that within one year Gregory Peck portrayed both Atticus Finch ${ }^{94}$ and Sam Bowden (the law-abiding southern gentleman lawyer of the first Cape Fear ${ }^{95}$ ). In both roles, he served as a righteous trial lawyer attempting justice in the courtroom (in the first instance, seeking acquittal of a black man falsely accused of rape, and in the second, defending a white man accurately accused of rape). At the conclusion of both films, however, this gentlemanly southern lawyer has been forced to take the law into his own hands, ultimately violating the law in both cases (covering up a murder in one and actually committing a perhaps justified (self-defense) murder in the other), all in the name of justice. We, the audience, complicitly applaud this man of noble character who achieves justice with all the American approbation of a good western well fought. ${ }^{96}$

Is lawyer character constituted from ordinary human mettle? Strength of character? Commitment? Loyalty? Honesty? Selflessness and protection of others? Good judgment? ?" $^{97}$ Leadership? Or, is good lawyerly character supposed to be faithful to the rules of law, ethics, and procedure? Literary

92. See The Practice: Cross-Fire (ABC television broadcast, Mar. 4, 1999); The Practice: Target Practice (ABC television broadcast, Mar. 7, 1999).

93. Most recently codified in the RestaTEMENT (THIRD) OF THE LAW GOVERNING LAWYERS (2001).

94. See TO KILL A MOCKINGBIRD (Universal International Pictures 1962).

95. CaPe Fear (Melville-Talbot Productions 1962). See Francis M. Nevins, Cape Fear Dead Ahead: Transforming a Thrice Told Tale of Lawyers and Law, 24 LEGAL STUD. F. 611 (2000). (This version of Cape Fear was screened at the symposium at which the papers in this issue were presented.)

96. For similar claims about the complexity of our adherence to the rule of law, good character, justice, and the white hats winning in American film, see Steven Lubet, The Man Who Shot Liberty Valance: Truth or Justice in the Old West, 48 UCLA L. REV. 353, 359 (2000), which argues that the man who shot Liberty Valance should have been indicted for murder.

97. Does good judgment include the ability to judge with discretion and wisdom, and not be overly restricted or cabined by the law and the rigidity of rules? See Simon, Ethical Discretion, supra note 9; Simon, Moral Pluck, supra note 9. 
and popular depictions of lawyers dramatize these tensions, as legal philosophers debate the differences between morality and positive law. ${ }^{98}$ In the movies and on television good lawyer character just as often demonstrates a departure from the rules of law in the name of a greater justice, ${ }^{99}$ as it does conformity to it. We may want to question why this is so-do these fictional depictions help us develop role models committed to justice, or is there also a danger that good and strong character allows us to take justice, and law (as long as we are "worthy" and morally justified) into our own hands? Perhaps it is in our actions that our true characters are revealed, and it is to those particular acts that I now turn.

\section{THE ETHICS OF ACTS IN POPUlAR CULTURE}

When I began teaching legal ethics and professional responsibility over twenty years ago, it became clear to me that for law students who had yet to practice law, legal ethics issues became most interesting and salient to them when they could view or read about a concrete ethical dilemma that plagued a lawyer (especially if the action was not complete and choices were still to be made). And so, 1 began to teach legal ethics with "stories ripped from the headlines," ${ }^{, 100}$ as I wrote simulations and role-plays for students to enact, discuss, and dissect in class. ${ }^{101}$ Sometime after 1 began teaching professional responsibility, L.A. Law premiered in my thenhometown, Los Angeles, and students were never more eager to talk about legal ethics as they asked after each show "can they do that?" As a pedagogue with a long pedigree in experiential education, I learned a valuable lesson from my students-legal ethics and professional responsibility issues were best learned and studied in situ. If students could be in role and have to act as lawyers, they would really confront the

98. See, for example, LON L. FULLER, THE MORALITY OF LAW (rev. ed. 1969), and H.L.A. HART, THE CONCEPT OF LAW (1961).

99. There are many examples in popular culture of lawyers violating both "little" rules, ethics rules, or major laws in order to accomplish greater justice. Consider, for example, Frank Galvin's stealing mail to get information in The Verdict, the deception used to get important files in IN THE NAME OF THE FATHER (Universal Pictures 1993), or the theft of confidential files in GRISHAM, THE STREET LAWYER, supra note 26, at 144-80. From watching modern movies or reading modern novels and thrillers, one would certainly conclude that the end justifies the means for most lawyers and justice-seeking paralegals.

100. This is the current tag line used in advertising for NBC's Law \& Order.

101. See MURRAY L. SCHWARTZ \& CARRIE MENKEL-MEADOW, LAWYERS AND THE LEGAL PROFESSION: CASES AND MATERIALS (2d ed. Supp. 1991); MURRAY L. SCHWARTZ \& CARRIE MENKEL-MEADOW, TEACHER'S MANUAl FOR LAWYERS AND THE LEGAL PROFESSION (1985). 
intersections of rules, ${ }^{102}$ professional and personal conceptions of morality, and the sociology of the profession's influence on legal ethics actions (hierarchical, economic, and social demands on the professional). Roleplays and simulations are one way to place students in the role of a lawyer who must make actual ethical choices and decisions about actions. But over the years I have tapped the richness of vicarious experiential learning that can occur by studying legal actions taken as depicted in literature, movies, and television. ${ }^{103}$

Watching lawyer stories in the movies and on television, or reading mysteries and legal thrillers now enables us to spot issues by the hundreds, ${ }^{104}$ and really requires that all lawyer and law student viewers keep their ethics rules close at hand. Seeing acts taken or contemplated vividly depicts the actual ethical dilemmas that lawyers face and helps us consider what other choices are available.

Modern popular culture has gone so far as to actually depict ethical proceedings, though often inaccurately. Ethics claims and charges were occasionally brought on L.A. Law (for solicitation of clients, conflicts of interests, and such) and are now quite common on The Practice, where we have actually viewed several disciplinary proceedings. Most often the writers, probably for dramatic reasons, allow ethics issues to be raised in the case-inchief, ${ }^{105}$ when in fact they would most often be dealt with separately, either in a disciplinary hearing or in a malpractice action. ${ }^{106}$ Beyond ethical rule violations, popular culture treatments of lawyers raise such compelling professional and personal moral issues as what to do with incriminating

102. In California such rules are complicated by the fact that California has never passed the American Bar Association's MODEL RULES OF PROF'L CONDUCT (1999), but has its own Business and Professions Code, CAL. BUS. \& PROF. CODE $\$ \$ 6067-6228$ (Deering 2001), and Rules of Professional Conduct, CAL. RulES OF PROF'L CONDUCT (2000).

103. See Menkel-Meadow, Telling Stories, supra note 1.

104. When the movie Class Action premiered, I gave "extra credit" on my legal profession exam for those students who could at least "spot" all the ethical issues depicted in that film. By my count there were over thirty separate potential rule violations or other questionable activities, including among other things, obvious conflicts of interest (father and daughter on opposite sides of a case and talking about it, a hidden document, frivolous and harassing discovery behavior, and witness hiding and coaching, just to name a few). While issue spotting takes some of the fun out of entertainment media, it has a powerful learning effect by making dry rules come to life and remain both vivid and remembered. The challenge for teachers, of course, is that students should remember the "ethically correct" responses to a dilemma, not the often more lurid and dramatic (but effective), transgressions that turn out, at least in the movies, to right grave injustices.

105. As in the final settlement negotiations with the judge in The Street Lawyer.

106. Exceptions, of course, include motions to disqualify counsel in conflicts of interest situations, which would be heard in the context of a substantive case, and FED. R. CIV. P. 11 claims about frivolous or incompletely investigated claims or statements. Discovery rules, such as Federal Rules of Civil Procedure 26, and 37 also permit consideration of sanctions and other penalties for unethical conduct during the discovery phases of a lawsuit. 
physical evidence, ${ }^{107}$ sleeping with opposing counsel, ${ }^{108}$ one's client, a juror, or the presiding judge, ${ }^{109}$ whether to falsely accuse an innocent person, ${ }^{110}$ how to get information or documents from the other side without formal discovery, ${ }^{11}$ and when and how a lawyer may reveal confidential information to others. While The Practice has literally become an ethics course $^{112}$ with at least one ethical issue an episode (and sometimes more), legal ethics and personal morality are clearly on the minds of all modern writers about legal issues.

While I do not assert here that the ethics issues dramatized in popular culture are necessarily representative of what actually happens in law practice, ${ }^{113}$ it is useful for scholars to study the actual occurrence of ethics violations and compare them to treatments in popular culture. It is instructive to canvass and analyze what legal acts have been demonstrated as ethical quandaries or dilemmas in the popular media.

It is possible to construct a temporal template of ethical issues depicted in the popular media from the beginning of the lawyer-client relationship to the end of an appeal or transaction (or to a murder for those relationships that end really badly). 'Russell Banks's The Sweet Hereafter ${ }^{114}$ tells the fic-

107. Did Ellenor have to turn over to the prosecutor the severed head brought to her office by the accused (and, as we later learn, guilty) defendant? See The Practice: The Battlefield (ABC television broadcast Oct. 25, 1998).

108. Bobby Donnell and Helen the prosecutor sleep together on two episodes of The Practice.

109. Jimmy has a relationship with a judge on The Practice.

110. On The Practice the defense team routinely tries to incriminate someone other than the accused defendant under its notorious "Plan B."

111. See, e.g., A CIVIL ACTION, supra note 60; ClASS ACTION, supra note 72; IN THE NAME OF THE FATHER, supra note 99; THE VERDICT, supra note 66.

112. See Goldberg, supra note 29.

113. See, e.g., Asimow, Bad Lawyers, supra note 2 (contrasting and comparing polling data on perceptions of lawyers in the general population with depictions in the movies); Stewart Macaulay, Images of Law in Everyday Life: The Lessons of School, Entertainment and Spectator Sports, 21 LAW \& SOC'Y REV. 185 (1987); Macaulay, supra note 3; see also William T. Gallagher, Ideologies of Professionalism and the Politics of Self-Regulation in the California State Bar, 22 PEPP. L. REV. 485 (1995); Manuel Ramos, Legal Malpractice: No Lawyer or Client Is Safe, 47 FLA. L. REV. 1 (1995); Manuel Ramos, Legal Malpractice: The Profession's Dirty Little Secret, 47 VAND. L. REV. 1657 (1994); Manuel Ramos, Legal Malpractice: Reforming Lawyers and Law Professors, 70 TUL. L. REV. 2583 (1996) (suggesting that large-firm lawyers commit as many, if not more ethical transgressions as the commonly assumed ethical violators-solo or small-firm lawyers); SUSAN SHAPIRO, TANGLED LOYALTIES (forthcoming 2002) (reporting an empirical study of conflicts of interests practices in all sized practices).

1I4. RuSSELl BANKS, THE SWEeT Hereafter (1991); THE SWEET HEREAFTER (Fine Line Features 1997). See Tory McAdams, Blame and The Sweet Hereafter, 24 LEGAL STUD. F. 599 (2000), and Austin Sarat, Imagining the Law of the Father: Loss, Dread and Mourning in The Sweet Hereafter, LAW \& SOC'Y REV. (2000), for more detailed treatments of this narrative of loss and the legal system told from the point of view of many different participants in the story. 
tionalized story of an actual bus accident that killed a number of children and had a great impact on many lives. The story is told from the point of view of many different participants in the story, but from Mitchell Stephen, Esq., we learn how clients are involuntarily solicited, because lawyers are angry and are able to harness their anger to compensate other people. For Mitchell Stephens, "[t]here are no accidents" sible for things that go wrong, and it is the plaintiff's lawyer's job to find someone (with deep pockets) to blame and to pay up so the injured can be compensated. This is class justice and the lawyer must orchestrate it: "I wanted a mean lean team, a troop of vengeful parents willing to go the route with me and not come home without some serious trophies on our spears." ${ }^{116}$ As Stephens describes himself, he lives for these "disaster negligence suits.... Nothing else provides me with the rush that I get from cases like this .... It's almost like a drug. It's probably close to what professional soldiers feel, or bullfighters." ${ }^{\prime 17}$ Stephens tells us how he ropes in mourning parents and what he does when one of them, Billy Ansel (who has lost two children), resists him, and how he lies to make his case. We also learn how Stephens appears to his clients (from their point of view), as one of the injured children, Nichole Burnell, takes his measure when she is interviewed and prepped for a deposition (which she later deliberately ruins by telling her own truth and seeking justice against another wrongdoer, her own abusive father, rather than against any of the actors in the accident). Although Nichole likes Mr. Stephens, he makes her feel greedy and dishonest by preparing for a deposition to get the money her parents want from her injury. Nichole overhears a conversation Billy Ansel has with her father about how the lawyers are all suing each other because some plaintiffs have signed up with more than one lawyer, and the reader feels the pain of grieving parents trying to make sense of what has happened and what could happen to them, while the lawyers fight to profit from their misery. ${ }^{118}$

In contrast, Jan Schlichtmann's real-life, initially unwanted plaintiffs grow slowly from distrust of a legal system that will not do anything for a widening group of injured people (never big enough for the class action numbers that would have been possible in the Buffalo Creek disaster ${ }^{119}$ ) to

115. BANKS, supra note 114 , at 91 .

116. Id. at 113 .

117. Id. at 120-21.

118. What a passage from which to teach the spaces between permissible and impermissible solicitation. See, e.g., Ohralik v. Ohio State Bar Ass'n, 436 U.S. 447 (1978); 1n re Primus, 436 U.S. 412 (1978).

119. When Gerald Stern, the lawyer in the Buffalo Creek dam disaster and author of one of the first lawsuit memoirs, see STERN, supra note 59, is queried by my civil procedure classes about 
become increasingly committed to their lawsuit, and to see their lawyer as a mixed bag of altruistic and selfish motives.

Atticus Finch is actually pressed into service in representing Tom Robinson by the judge handling the case, but he tells a good story to his daughter about the responsibility of lawyers to take unpopular clients and cases (the " $n$ " word is used in both the book and the movie, circa 1960-1962). In so doing, he has given us all a model and argument for the importance of pro bono publico and even court-appointed work, especially in criminal law. Representing unpopular clients and taking court appointments has continued on The Practice, while in past years, paying clients have been more the rule on L.A. Law and on the short-lived Murder One $e^{120}$ (a show inspired by the public's hunger for criminal celebrity trials following the coverage of the O.J. Simpson trial). A Civil Action made the economics of contingent-fee lawyers clear to the viewing public, and began to address the inevitable conflicts of interests that accompany virtually any payment scheme for lawyers. ${ }^{121}$

From client acquisition, modern films and movies depict a variety of ethical dilemmas in representation (still mostly restricted to the more dramatic world of litigation and courtrooms, rather than transactional lawyering ${ }^{122}$ ). For example, The Practice has several times, in different settings, explored issues of confidentiality-when must or can a lawyer reveal private, confidential information to others? $?^{123}$ And when Bobby and Helen were dating, the show explored difficult, but I suspect increasingly common, professional dilemmas when lawyers on opposite sides of cases date or live with each other, hear confidential information in phone

why he didn't file that lawsuit as a class action, he answers that he wasn't taught about class actions when he attended law school-so what we teach matters! Of course, at the time Gerald Stern brought his suit, no one thought that Federal Rule of Civil Procedure 23 applied to tort claims, in which injuries were thought to be individualized. See Carrie Menkel-Meadow, Ethics and the Settlements of Mass Torts: When the Rules Meet the Road, 80 CORNELL L. REV. 1159 (1995).

120. Murder One (ABC television broadcast, 1995-1997).

121. The contingent fee puts a premium on quick settlement for the plaintiff's lawyer and the hourly fee may result in "overworking" a case. See Murray L. Schwartz \& Daniel J.B. Mitchell, An Economic Analysis of the Contingent Fee in Personal Injury Litigation, 22 STAN. L. REV. 1125, 1137-39, 1143 (1970); see also HERBERT M. KRITZER, LET'S MAKE A DEAL: UNDERSTANDING THE NEGOTIATION PROCESS IN ORDINARY LITIGATION (1991).

122. There are a few wonderful exceptions to this litigation rule, most notably the novels of Philadelphia lawyer, Arthur R.G. Solmssen, particularly ARTHUR R.G. SOLMSSEN, THE COMFORT LETTER (1975), which chronicles the ethical and other issues in a tender offer. See also JAMES C. FREUND, ANATOMY OF A MERGER (1975) and a variety of non-fictional accounts of lawyers' roles in big deals, for example, STEWART, supra note 80, and JAMES B. STEWART, DEN OF THIEVES (1991).

123. See MODEL RULES OF PROF'L CONDUCT R. 1.6 (1999). California protects client confidentiality, with relatively few exceptions, more strongly than any other jurisdiction. See CAL. Bus. \& PROF. CODE $\$ 6068(\mathrm{e})$ (Deering 2001). 
conversations, and see messages and papers left lying around the house. ${ }^{124}$ The lawyers on The Practice have grappled with what to do with physical evidence, when they can "rat" on their own client, and many thorny witness preparation issues. In a modern replay of the now classic client "coaching" scene of Anatomy of a Murder, ${ }^{125}$ lawyers tell their clients what the law is before learning the facts. A guilty-feeling Helen, as prosecutor, actually testifies against one of her colleagues whom she believes wrongfully suggested testimony to a material witness. Ellenor Frut commits one of the most egregious, but clever, unethical acts (can you think of what ethical rules she violates?) when she advises a client who has been in an accident and has been drinking, to finish the open bottle at the scene of the accident "to calm his nerves"-and thereby destroy the accuracy of any breathalyzer test. The lawyers of The Practice have conflicts of interest galore-they sleep with each other and the judge, they work both sides of a case, they take on civil matters beyond their competence, but at least they have explicit ethical conversations about what they are doing. There is not only talk about the law, possible ethical violations, and consequences to their firm and their clients, but they do in fact get called on some of their questionable behavior.

Competence is questioned in popular culture, whether by the satire of Joe Pesci's performance in My Cousin Vinny, ${ }^{126}$ by the too-young and inexperienced colleague in Grisham's The Rainmaker, ${ }^{127}$ by the all-too-common substance abuse of Frank Galvin in The Verdict, ${ }^{128}$ by the actual Rule 11 motion filed against Jan Schlichtmann for not adequately investigating and supporting his complaint filing, ${ }^{129}$ or by the impressionability of a lawyer who believed she was zealously representing her client, but who may in fact have been subject to a "con job" that cost her her freedom and her law license. ${ }^{130}$ Scott Turow counters these images of incompetence by providing

124. The questions of spousal immunity for testimony combine with conflicts of interest when lawyers who are related to each other are on different sides of the same matter are complex enough, see MODEL RULES OF PROF'L CONDUCT R. 1.8(i), without considering more modern living and dating patterns (not to mention same-sex partners, who will not have the full protection of spousal immunity to prevent them from testifying about what they hear from each other about legal cases worked on).

125. ROBERT TRAVER, ANATOMY OF A MURDER (1958).

126. MY COUSIN VINNY (20th Century Fox 1992)

127. GRISHAM, THE RAINMAKER, supra note 48.

128. Drug and alcohol abuse is one of the most common causes of disciplinary action and incompetence in case handling. See, e.g. , RICHARD A. ZITRIN \& CAROL M. LANGFORD, LEGAL ETHICS IN THE PRACTICE OF LAW 533-54 (1995).

129. See HARR, supra note 60, at 85-119.

130. See JANET MALCOLM, THE CRIME OF SHeILA MCGOUGH (1999); Steven Lubet, Rumpled Truth on Trial, 94 NW. U. L. REV. 627 (2000) (reviewing Malcolm skeptically). 
perhaps the most detailed and accurate accounts of the hard work that both prosecutors and defense counsel put into their jobs-in investigation, case preparation, courtroom strategy, and courtroom execution ${ }^{131}$ - even if some of the lawyers and judges turn out to be corrupt or worse. ${ }^{132}$

As most popular culture continues to explore the drama of the courtroom, I am personally interested in recent turns to more typical locales of lawyers' work-the bargaining table. Still located mostly in litigation contexts, the ethics and practices of lawyers in settlement conferences present serious ethical dilemmas, hardly responded to by the rules. While The Practice lawyers engage in plea-bargaining and tense settlement negotiations every time they take on a medical malpractice or products liability case, the settlement conference is becoming a more common staple of legal drama. My personal favorite is the blatant ethical violation in The Verdict, the premise of which is needed to fuel the rest of the film. Frank Galvin turns down a large, and certainly likely to be accepted by his client, settlement offer from the Catholic Church (which controls the hospital which mistreated his comatose client) without even talking to his client (the family of the comatose woman). In direct violation of Rules 1.2, 1.3, and 1.4 (and all of their predecessors that were in effect in Massachusetts at the time of the film ${ }^{133}$ ), Galvin turns down the offer. Thus, the case (and the film) can proceed to the more dramatic confrontation in the courtroom, where Galvin, overcoming his alcoholism and violating some laws by stealing mail to get information, triumphs over a major and well-staffed law firm.

Michael Brock's lawsuit against the developer who wrongfully evicted his homeless clients is completed in a settlement conference, this one in a judge's chambers with Brock's own ethical transgressions (deception used to get evidence and confidentiality violations) as part of the negotiation

131. See, for example, SCOTT TUROW, BURdEN OF PROOF (1990), SCOTT TUROW, THE LAWS OF OUR FATHERS (1996), SCOTT TUROW, PLEADING GUILTY (1993), SCOTT TUROW, PRESUMED INNOCENT (1987), and more recently in SCOTT TUROW, PERSONAL INJURIES (1999).

132. Scott Turow was himself implicated in a disciplinary charge in Chicago, because he continues to practice law while writing about it. This, in addition to his great talent, might explain why his thrillers are so much more legally accurate and interesting than the work of his fellow bestselling authors. More recently, Turow, as a result of his own involvement as appellate counsel in two death penalty cases, has begun speaking out against the death penalty. See Scott Turow, Speech at Harvard Law School (Apr. 2001).

133. See MODEL RULES OF PROF'L CONDUCT R. 1.2, 1.3, 1.4 (1999), especially comment 1 to Rule 1.4 in which lawyers are admonished to communicate all settlement offers to their clients and provide them with enough information to evaluate the offer. Some have defended Galvin, because the settlement offer was not in writing, as required for some civil offers (criminal plea offers must be transmitted no matter how communicated, see Rule 1.2(a)). See also MODEL CODE OF PROF'L RESPONSIBILITY EC 7-7, EC 7-8 (1980), which was in effect in Massachusetts in the early 1980s. 
agenda. ${ }^{134}$ Similarly, while nothing overtly in violation of the rules transpires, Jonathan Harr's descriptions (from one side only ${ }^{135}$ ) of the various settlement negotiations (meetings at the Ritz Carlton in Boston and W.R. Grace headquarters in New York) in A Civil Action provide us with some entry into the world of lawyer impression management, guarded information exchange, and normal "deception." 136

Modern treatments of lawyers demonstrate good acts as well-not all is sex, lies, and videotape. Lawyers like Frank Galvin and Jan Schlichtmann, as well as paralegal Erin Brockovich, demonstrate the power of persistence and the necessity of hard, long, and detailed fact investigation. Although in trial movies and television shows it sometimes looks like victory goes to the clever and the articulate, in truth we seldom see anymore the contrived final question of a devastating and surprising Perry Mason-like crossexamination. As discovery has replaced surprise in trial, popular culture is slowly catching up with what makes good lawyers in real life-hard work! Hard work and long hours get their share of criticism, ruining marriages in The Firm ${ }^{137}$ and The Street Lawyer, not to mention adultery on the job with coworkers. No one could accuse modern lawyers depicted in the media as a lazy bunch-even the "you can have it all" glamour pusses of L.A. Law. Good lawyering (as well as realistic lawyering) takes hard work, as the "bill and tell" books painfully recount, and virtually all of these modern tales, both fact and fiction, do want us to consider the consequences of hard professional labor on personal lives.

Changes in the practice of law, both in the work done and in the demographic composition of the legal profession, are beginning to seep into modern depictions of discrimination issues (partnerships, power, decisionmaking authority for minority and women attorneys, and sexual harassment). In this, L.A. Law showed us other kinds of lawyer work, including Arnie Becker's divorce work, ${ }^{138}$ tax, and corporate work. Leland McKenzie

134. Grisham needs to bone up on his legal ethics studies. The judge in the case would have no authority to mete out suspension-from-practice penalties within the substantive case, but it does have dramatic appeal, especially by adding another issue to the negotiation agenda.

135. Jonathan Harr wrote his journalistic account of A Civil Action by shadowing Schlichtmann. See HARR, supra note 60. For the most part, the defense counsel did not share their strategies or other information with him. This is why fiction may illuminate more than fact. In fictional works, we often get entry into the lawyer's heads and actions from all sides of a case (see, for example, BANKS, supra note 114), especially if there is an omniscient narrator.

136. See MODEL RULES OF PROF'L CONDUCT R. $4.1 \mathrm{cmt}$. 1 (1999), which permits some lack of candor in settlement negotiations.

137. GRISHAM, THE FIRM, supra note 48.

138. Now depicted in the lawyer shows focusing on female attorneys, such as Family Law (CBS television broadcast, 1999-current) and Judging Amy (CBS television broadcast, 1999current). 
even served as an arbitrator in what has to be the first depiction of ADR on screen. ${ }^{139}$ As creators of popular culture begin to realize that lawyers do many things besides trying cases, I look forward to depictions of some of the equally difficult and dramatic ethical issues that are encountered in other forms of legal work: conflicts of interest in alternative dispute resolution involving repeat players, corporate deal making, disclosure obligations in transactional negotiations and public offerings, lawyers paid with stock options in dotcoms, and now the fall-out from "dot-gones." ${ }^{140}$

\section{Professional Ethics in Popular Culture}

I have very briefly here reviewed some of the ethical issues, large and small, that lawyers face in practice when that practice is dramatized in the popular media. Lawyers as people confront the challenges of making choices about what work to do, what clients to represent or serve, how to act on their behalf, and how to connect their professional selves with their personal beings. I have suggested here that the images of lawyers are far more interesting, complex, and nuanced than earlier and more cardboard, or caricatured, depictions have been. Atticus Finch is no longer the uncomplicated hero that we once thought he was when we measure him against current standards of complicity with a wrongfully racist society. Frank Galvin was a drunk who found redemption and reconnection to his profession in taking one case seriously. Eugene Young, Ellenor Frut, and Bobby Donnell hang out with us week after week, as they explain themselves to each other and to us, with all the complexities of life in a tough urban criminal practice. The sideline stories about the relations of personal lives to professional ones in most earlier depictions of lawyers have given way to more about the whole person. Increased professional and public debate about both lawyers ${ }^{141}$ and lawyers' complicated ethical $\operatorname{codes}^{142}$ have themselves complexified the answer to the question "can they do that?"

139. So far as 1 can tell, the second was Michael Crichton's seriously flawed and distorted mediation scene in the movie version of DISCLOSURE (Warner Bros. 1994). But as always with Michael Crichton, he wanted to demonstrate that he was on the "cutting edge" of a topical issue-mediation is clearly one of those for the legal profession.

140. How will lawyers with stock options be involved in picking bankruptcy counsel? Some of these issues revisit old and dramatic issues for lawyers, such as serving on boards of directors or having conflicts of interests when companies have problems. See supra note 20.

141. See, e.g., MARY ANN GLENDON, A NATION UNDER LAWYERS: HOW THE CRISIS IN THE LEGAL PROFESSION IS TRANSFORMING AMERICAN SOCIETY (1994); ANTHONY T. KRONMAN, THE LOST LAWYER: FAILING IDEALS OF THE LEGAL PROFESSION (1993); DEBORAH L. RHODE, IN THE INTERESTS OF JUSTICE (2001).

142. See, e.g., ETHICS IN PRACTICE, supra note 13; SIMON, supra note 9; see also THE GOOD LAWYER, supra note 31; DAVID LUBAN, LAWYERS AND JUSTICE: AN ETHICAL STUDY (1988). 
Yet, before I conclude, I want to consider how lawyers depicted in popular or high culture compare to other professionals with ethical problems.

It is surprising that with all the burning issues in biomedical ethics (abortion, euthanasia, scarcity of donor organs, and high drug prices for the developing world), the depiction of doctors in the popular media continues to be mostly ethically "favorable"-attention is drawn more to substantive issues of diagnosis, treatment, cure, or personal lives, than to medical ethics. Although the classic treatment of professional character in my view is George Eliot's Middlemarch, ${ }^{143}$ in which Dr. Lydgate confronts conflicts between his idealistic hopes for modern science and the greedy economic needs of his wife and the traditional values of his community, few modern medical shows have looked at the individual doctor's medical ethics with quite the same scrutiny as that applied to lawyers. It is true that ER has looked at substance abuse and dysfunctional personal lives, but with the exception of Dr. Kovac's recent lapse in his treatment of a drunk driver, these doctors seem never to do any harm ${ }^{144}$ and pitch in for each other whenever they can. Real medical decisions about when to intervene and when to either let die or facilitate death have captured the Supreme Court and much scholarship. ${ }^{145}$ We know these life and death decisions go on every day in real life, but they are somewhat absent in some of our more prominent movie and television depictions-are the issues scarier to the public than the misfeasance of lawyers? We will all die, but not all of us have to use lawyers-is that it? Shouldn't we care just as much about the ethics of the doctors that we all go to?

Recent political scandals and the new television program The West Wing have increased the depiction of ethical dilemmas faced by our public figures and politicians. Here once again, George Eliot was there early on with her novel, Felix Holt ${ }^{146}$ in which she used character studies to depict the utopian promises and goals of politicians who seek the common good, with those who are more content to muddle along in the status quo for personal aggrandizement or personal gain. ${ }^{147}$ In political ethics, the juxta-

143. GeORGE Eliot, MiddlemarCH (David Carroll ed., 1992) (1872).

144. But see the season finale: Dr. Mark Greene lets a murderer/child abuser die, rather than try to revive him via electric shocks. And, he covers up his actions by repeatedly shocking the air. ER: Rampage (NBC television broadcast, May 17, 2001).

145. See, e.g., Cruzan v. Dir., Mo. Dep't of Health, 110 S. Ct. 2841 (1990); Louis Michael Seidınan, Confusion at the Borders: Cruzan, "The Right to Die" and the Public/Private Distinction, 1991 SUP. CT. REV. 47.

146. GeOrge Eliot, Felix Holt: The Radical (Lynda Mugglestone ed., 1995) (1866).

147. While Felix Holt was often called her "political novel," George Eliot was, in fact, more interested in character study and how the concrete politics of the Reform Act of 1832 had not entirely succeeded. See id. Introduction. The novel is ultimately about the ethical wielding of power, both public and personal. 
position of the relation of the possible to the good provides challenges at both public and personal levels that can echo some of the dilemmas of legal ethics.

Writing some decades later than George Eliot, William Dean Howells, in his time a rival in American literary popularity to Henry James, touched on the nascent ethical issues facing American journalism in the late nineteenth century. Often considered the first novel about American divorce, In a Modern Instance ${ }^{148}$ also reports on the transformation of American journalism from independent reporters to owner-dominated editorials. It is interesting that popular and scholarly accounts of journalistic ethics continue to speak of "objectivity" in the news, ${ }^{149}$ when as early as 1880 , literary treatments of journalism suggested an already-compromised set of ethical standards as owners of newspapers selected topics and "slants" on the news. William Dean Howells would have known first hand of these conflicts, having moved, like so many of our modern lawyer-authors, from his first craft of magazine editor to his second of novelist. Bartley Hubbard, the protagonist who practices "the new journalism," represents the "fraying of the social fabric" of American ethics when he succumbs to "the new journalism" in stealing the writing of a story from his friend, drinking, and cheating on his wife (which leads her, a symbol of pure American New England solidity, to have to divorce him). The divorce in this novel, though located in conjugal relations, is clearly meant to represent the separation of "old" American ethics in journalism and work from the newer, more commercial forms. Does the theme of increased commercialism sound familiar?

Journalists became heroes again, briefly, in American popular culture with the unfolding of the Watergate saga and the tireless investigation of Woodward and Bernstein ${ }^{150}$ - so that all journalists wanted to be "investigative journalists." As our investigative stories have turned more tawdry, and as some of them have been exposed as falsifications, ${ }^{151}$ journalists should be on the popular ethical chopping block too. But are they? One recent attempt to depict an investigative reporter ${ }^{152}$ (by the creators of Law $\mathcal{E}$ Order) failed after only a few weeks, even as more lawyer shows were

148. William DEAN HOWElls, IN A MODERN INSTANCE (Edwin Cady ed., 1988) (1882).

149. See Michael SCHudson, Discovering THE News: A SOCIAL History of AMERICAN NEWSPAPERS (1978).

150. See Robert Woodward \& Carl Bernstein, All the President's Men (1974).

151. See, e.g., Robin Pogrebin, Rechecking a Writer's Facts, A Magazine Uncovers Fiction, N.Y. TIMES, June 12, 1998 at A1; New Republic Associate Editor Stephen Glass Fired for Fabricating Stories, at http://www.ndsn.org May June 98/netnews5.htmI.

152. See Deadline, (NBC television broadcast, 2000). 
beginning to appear. ${ }^{153}$ Don't more people read newspapers and magazines than hire a lawyer? Why aren't they interested in how their news is written and produced?

In popular culture's most recent depiction of professional ethics, which has been very evocative for legal ethics teachers, Ishiguro's The Remains of the Day ${ }^{154}$ focuses on a single butler who loyally serves his master, a British gentleman with diplomatic ties to the German Nazi regime. Stevens, the butler, has inspired a movie ${ }^{155}$ and much legal commentary. ${ }^{156}$ His loyalty to his master provokes lawyers, and all who serve as agents, to question whether we can be judged by association with those whom we choose to serve. 1s Stevens complicit in his master's political leanings by caring for his household? Ishiguro suggests that he is. In his efforts to be a loyal servant to his master, Stevens misses his father's death on the evening of a meeting with the Germans at the master's estate, and he loses his chance for romance and a fulfilling relationship with the sensitive Miss Kenton. Ishiguro's butler, Stevens, is emblematic of the issues discussed here. Stevens appears to be of impeccable character-loyal to a fault, efficient, honest, and hardworking. But, his slavish devotion to his professional identity and the tasks set before him everyday cause him to miss the answers to the big questions in life. At the end, he has come to question his devotion to his master, whom he begins to conclude is not the honorable man he thought him to be. He realizes that by performing his acts reflexively, one after another, as a person puts one foot before another, he has lost himself in the high quality of his professional performance. We, the reader, are witness to each act, as they cumulate to make a character. We can see the folly of the choices he makes.

Stevens, the butler, can tell us many things about lawyer ethics in popular culture and in reality. First, it is the cumulation of choices and acts that make the character of a man (or woman) in professional role, and it is important to witness each one, as recent television shows and movies allow

153. See 100 Centre Street (A\&E television broadcast, 2001); Ally McBeal (Fox Network television broadcast, 1997-current); Family Law (CBS television broadcast, 1999-current); First Years (NBC television broadcast, 2001); Judging Amy (CBS television broadcast, 1999-current).

154. ISHIGURO, supra note 14.

155. See THE REMAINS OF THE DAY (Columbia Pictures 1993)

156. The story in The Remains of the Day appears to be a fictionalized account of "the Cliveden set," which describes Lady Nancy Astor's (an American and the first woman to sit in the British parliament) and her husband's rather cozy relationship to several Nazi office holders. Cliveden had a butler, who served as loyally as Stevens for many years, and found even his resignation would not be accepted by Lady Astor. See JAMES FOX, FIVE SISTERS: THE LANGHORNES OF VIRGINIA (1998); see also supra note 14. 
us to do. ${ }^{157}$ Character dispositions form the default choices that suggest themselves to characters. But in the movies, as in real life, there is always the chance that a particular circumstance will cause one to act differently, or to make a particular choice, or the chance that a single act or event may change our very being (or at least our professional orientation, as Michael Brock from The Street Lawyer demonstrates). Second, it may indeed help to have a professional code of ethics. It is harder for Stevens to ask if he can "do that" (refuse his master's orders) without an ethical code beyond that of the human ethical code to guide him. Butlers must serve or quit; lawyers may have legally sanctioned grounds to withdraw when particular acts or client goals are unsavory. ${ }^{158}$ Third, we do learn to think ethically and empathetically by reading or viewing other people's (and other professional's) stories. Stories situate the action, provide some arguable justifications for actions taken, and provide the context in which the actor must act. In answering our question, "can they do that," we must look to sources such as ethics rules, cases, our consciences, or other professionals with whom to discuss our dilemmas.

Finally, I think in the end we realize that lawyers are not butlers, and that we are better served by the complexity of the competing loyalties of our professional roles. I think there are more depictions of lawyers' ethical dilemmas in popular culture than of other professionals precisely because we have several masters. As lawyers, we serve the private interests of clients, but we also serve the public interest of the justice system, as well as ourselves and our families. To have a job which, at the same time, faces both inward and outward, with private duties and responsibilities, but with public consequences, sets up a dramatic tension that creators of stories and other cultural artifacts cannot resist. To view the character and acts of lawyers, who are duty bound to do justice and must also serve and defend flawed human beings, appears to be an act of cultural consumption to which we cannot avert our eyes. My hope is that as the work of real lawyers becomes ever more complicated and diverse, the images of lawyering depicted in popular culture will reflect that complexity, so we can continue to ask "Can they do that?" with even greater sophistication and nuance.

157. This is why despite the higher production values of movies, I prefer television depictions of lawyers. There we can see more actions of the people we are watching and can feel the quotidian qualities of their existence. To the extent that character change occurs, we can see it coming from weeks of knowledge, and when it seems too sudden or unexplained by daily acts, we know it isn't real.

158. See MODEl RULES OF PROF'L CONDUCT R. 1.16 (1999). 
$* * *$

HeinOnline -- 48 UCLA L. Rev. 1338 2000-2001 